\title{
JOURNAL.RU
}

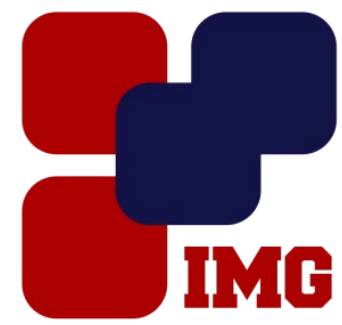

IVanov
Management
GROUP

Окасов Д.Б., Култанов Б.Ж., Рахимова Б.Б. Карагандинский государственный медичинский университет Караганда, Республика Казахстан

doi: 10.18411/lj-31-01-2017-3-04

idsp 000001:lj-31-01-2017-3-04

\section{Нарушение физиологических показателей сперматогенеза у крыс при ингаляционном воздействии пыле-солевыми аэрозолями}

\section{Аннотация}

Экспериментально исследованы физиологические показатели сперматогенеза у крыс при ингаляционном действии пыле-солевых аэрозолей Аральского моря в дозе 2 мг/мЗв остром эксперименте. Получено, что острое воздействие пыле-солевых аэрозолей Аральского моря индуцирует каскад молекулярных, клеточных и системных нарушений в организме экспериментальных животных и влияет на их репродуктивную функцию.

Ключевые слова: крыса, пыле-солевые аэрозоли, сперматогенез, сперматозоид, репродуктивная функция, физиологические показатели.

В последние годы началось изучение влияния стойких химических загрязнителей с гормональным эффектом на функционирование мужской и женской репродуктивной систем. Экотоксиканты, изменяя молекулярнобиохимические процессы в клетках, вызывают нарушение фундаментальных процессов дифференциации тканей и органов [1-4]. Следствием этого могут быть пороки развития различных органов, в том числе половой системы, а в дальнейшем - развитие гиперпластических и опухолевых процессов. Различия при отравлениях экологическими токсикантами между представителями разных полов вызвали большой интерес у медиков и экологов, поскольку гендерный подход к анализу воздействия разнообразных загрязнителей позволит лучше понять механизмы их действия на человеческий организм и найти пути их нейтрализации или выведения.

В настоящее время практически не изучено влияние пыле-солевых аэрозолей Аральского моря на репродуктивную функцию. В связи с этим нами было проведено экспериментальное исследование их влияния на репродуктивную функцию у крыс при острой ингаляционной затравке в дозе 2 мг/м3.

Целью данного исследования явилось изучение физиологических показателей сперматогенеза у крыс при действии пыле-солевых аэрозолей 
Аральского моря в эксперименте.

\section{Материалы и методы исследования}

Объектом исследования служили белые беспородные крысы-самцы исходной массой 180-200 г в количестве 27 особей, из них 7 особей в контрольной группе. Животные содержались на стандартном рационе вивария при обычной температуре и влажности воздуха в условиях естественной смены света и темноты. Учитывая циркадные механизмы регуляции биоритмов, все опыты проводили в одинаковое время суток и сезоны (осень, зима). Ингаляционную затравку пыле-солевыми аэрозолями Аральского моря проводили в течение 60 дней по 4 часа ежедневно. Забой животных проводили согласно международным рекомендациям по проведению медико-биологических исследований [5].

У животных опытной и контрольной групп после забоя извлекали семенники, промывали их охлажденным физиологическим раствором, затем экстрагировали суспензию сперматозоидов. Экстракцию осуществляли путем продолжительного рассечения придатков семенника в 10 мл охлажденного физиологического раствора. Экстракцию и все манипуляции со сперматозоидами проводились при температуре $250 \mathrm{C}$ по методу И.И. Миронова [6]. Для характеристики химического поражения оценивали общее состояние животных в динамике. Ежедневно проводили контроль изменения массы тела, состояния шерстяного покрова, двигательной и пищевой активности, а также клинических проявлений со стороны слизистых и кожных покровов, желудочно-кишечного тракта, учитывали количество летальных исходов.

\section{Результаты исследования и их обсуждение.}

В сперматозоидах крыс с моделью ингаляционной затравки в дозе 2 мг/м3 проводилось изучение физиологических показателей сперматозоидов крыс, оценивались количество подвижных и неподвижных их форм. В результате проведенного исследования установлено, что при воздействии пыле-солевых аэрозолей Аральского моря в дозе 2 мг/м3 в течение 60дней наблюдалось нарушение сперматограммы у крыс.

Обращает на себя внимание то, что число патологически измененных сперматозоидов крыс последовательно возрастало по сравнению с активно подвижными их формами. При ингаляционной затравке животных в дозе 2 мг/мЗотмечается постепенное уменьшение размеров семенников и нарушение генеративной функции. Первоначально поражаются сперматогонии, затем сперматоциты I и II порядков и сперматиды. Зрелые сперматозоиды повреждаются в последнюю очередь. Именно этой последовательностью событий с учетом влияния повреждающих химических факторов на процесс морфодифференцировки половых клеток у животных, на наш взгляд, можно объяснить увеличение числа неподвижных сперматозоидов на 60 сутки после затравки пыле-солевыми аэрозолями Аральского моря.

Нарушение морфодифференцировки может быть обусловлено рядом причин. Прежде всего, это повреждение активных участников процесса морфодифференцировки - белков цитоскелета- токсичными химическими веществами. По нашему мнению, наряду с упомянутыми причинами определенную роль в нарушении морфодифференцировки спермиев играет и 
нарушение простасом. На этапе превращения сперматид в сперматозоиды простасомы играют определяющую роль в направленном транспорте веществ, особенно ионов кальция и цинка, липидных и белковых компонентов, а также в регуляции энергетического статуса формирующихся половых клеток. Нарушение процесса формирования и транспорта простасом, а также ихслияние со спермиями, приводит к разнообразным нарушениям, в числе которых нестабильность мембран, текучесть плазмолеммы, дестабилизация хроматина. Известна роль простасом в стимулировании двигательной активности сперматозоидов. Вполне допустимо, что образующиеся свободные радикалы, токсичные липоперекиси, в том числе и в мембранах простасом, приводят к дестабилизации мембран, обеднению содержимого простасом, нарушению внутриклеточного транспорта простасом. В результате формируется пул химически неполноценных сперматозоидов, лишенных двигательной активности.

Исходя из полученных нами данных, повышение образования химических токсикантовв сперматогониях, сперматоцитах и сперматидах представляет большую опасность, поскольку приводит к развитию неполноценных сперматозоидов. Картина данных нарушений проявлялась в виде увеличения числа неподвижных сперматозоидов, появления атипичных форм с деформацией головки и удвоением аксонемы. Увеличение числа неподвижных и атипичных сперматозоидов при воздействии пыле-солевых аэрозолейможет быть индуцировано следующими факторами. Химические токсиканты могли взаимодействовать с белками цитоскелета, нарушая образование и морфодифференцировку спермиев и блокируя подвижность сперматозоидов.

Это приводит к изменению композиции белков в липидном бислое, что облегчает доступ химических токсикантовк мембранным фосфолипидам, нарушению проницаемости мембран, которые в дальнейшем приводят к повреждению целостности спермиев, изменению зарядового баланса, что объясняет появление атипичных спермиев на 60день эксперимента.

Таким образом, нами впервые показано, что острое воздействие пылесолевых аэрозолей Аральского моря индуцирует каскад молекулярных, клеточных и системных нарушений в организме экспериментальных животных, полученные результаты позволяют сделать вывод о том, что в сперматозоидах крыс наблюдается увеличение числа неподвижных форм и сокращению числа активно подвижных форм при остром воздействии пыле-солевых аэрозолей Аральского моря. 


\section{Литература}

1. Бекишев Б.М. Тяжелые металлы и хлорорганические пестициды в питьевой воде как факторы риска хронических эзофагитов в Приаралье. - Автореф. дисс канд. биол. наук. - Алматы, 2001. - 26 с.

2. Михайлов В.Н., Кравцова В.И., Гуров Ф.Н., Марков Д.В., Грегуар М. Оценка современного состояния Аральского моря // Вестник МГУ. Сер. География. - 2001. №6. - C. 14-21.

3. KultanovB.Zh., TatinaE.S., IbraibekovZh.G.Assessment of the histone like proteins treatment in mens sperm living at Aral sea region // Free radical biology and medicine. - 2015.- V.86. P.29.

4. КултановБ.Ж.,ЕдильбаеваТ.Т.,ТурмухамбетоваА.А., ДосмагамбетоваР.С.Окислительныйметаболизмприрадиационномпоражении Медицина труда и промышленная экология. - 2014. - №11. - С. 29-32.

5. Международные рекомендации по проведению медико-биологических исследований с использованием животных //Хроника ВОЗ. - 1985. - Т.39. - №3. - С.3-9.

6. Миронова И.И., Романова Л.А., Долгов В.В. Общеклинические исследования (моча, кал, ликвор, эякулят). - Москва-Тверь: ООО «Изд. Триада», 2005. - С.165-195. 